\title{
Microhabitat utilisation by an assemblage of temperate Gobiidae (Pisces: Teleostei)
}

\author{
H. K. A. Wilkins, A. A. Myers \\ Department of Zoology, University College Cork, Lee Maltings, Prospect Row, Cork, Ireland
}

\begin{abstract}
An assemblage of Gobiidae in Lough Hyne, southwest Ireland, was investigated to assess interspecific and seasonal differences in microhabitat utilisation. Five microhabitat guilds were distinguished using canonical correspondence analysis, comprising 2 semi-hyperbenthic guilds and 3 epibenthic guilds. Differential preferences for each environmental variable measured were examined using Jacobs' version of Ivlev's electivity index. Members of different guilds exhibited differential microhabitat use, whilst members of the same guild exhibited only subtle differences in microhabitat utilisation. Few seasonal variations were observed, with guilds maintaining their separation seasonally.
\end{abstract}

\section{INTRODUCTION}

Analyses of resource utilisation are essential in the study of animal ecology, with successful coexistance relying heavily upon differential resource utilisation. Schoener (1974) deduced that terrestrial animals partition resources along 3 axes - habitat, food, time in decreasing order. Ross (1986), on the other hand, suggested that in fish communities trophic partitioning was more important than habitat partitioning. However, habitat segregation is thought by many workers to be the most important aspect of resource partitioning in fish communities (Smith \& Tyler 1973, Gorman \& Karr 1978, Robertson \& Lassig 1980, Baker \& Ross 1981, Paine et al. 1982). The question of the importance of differential microhabitat use in fish assemblages has led to a wealth of investigations into the effects of environmental variables on fish community structure. However, most studies have been concerned with coral reef (Clarke 1977, Luckhurst \& Luckhurst 1978, Bouchon-Navaro 1986, Greenfield \& Johnson 1990. Pitts 1991) and freshwater (Werner et al. 1977. Grossman \& Freeman 1987, Grossman et al. 1987a, b, Greenberg 1991, Copp 1992) communities. Investigations have demonstrated the importance of substratum type (Luckhurst \& Luckhurst 1978), depth (Lindquist 1985, Illich \& Kotrschal 1990), and algal abundances (Carr 1989) in particular, in the structuring of fish communities
In this study, an assemblage of Gobiidae in Lough Hyne, southwest Ireland, was investigated in order to describe interspecific and seasonal differences in microhabitat utilisation.

While temperate Gobiidae have been the focus of several studies (Magnhagen \& Wiederholm 1982 Wiederholm 1987, Behrents Hartney 1989, Costello et al 1990, Wilkins \& Myers 1991, Costello 1992), none have considered how coexistence in an assemblage of Gobiidae is maintained seasonally over a range of habitats.

The assemblage in Lough Hyne consisted of: Gobius couchi Miller \& El-Tawil, Gobius cruentatus Gmelin, Gobius niger L., Gobius paganellus L., Gobiusculus flavescens (Fabricius), Pomatoschistus minutus (Pallas) Pomatoschistus pictus (Malm), and Thorogobius ephippiatus (Lowe). Two species of particular interest are $G$. couchi, to date known from only 4 localities (Miller \& El-Tawil 1974, Dyrynda \& Farnham 1985, Minchin 1988), and $G$. cruentatus, a Lusitanian species at the northernmost point of its distribution in southwest Ireland (Miller 1986)

\section{MATERIAL AND METHODS}

Lough Hyne is a sheltered marine lough, the ecology of which has been well documented (Myers et al. 1991); it contains a diversity of habitats, in a location suitable for year-round observation. 
Gobies were quantified using 10 sublittoral, $2 \mathrm{~m}$ wide continuous belt transects (Baker \& Crothers 1987), which were positioned in order to encompass the range of habitats existing within Lough Hyne (Fig. 1). Transects were $40 \mathrm{~m}$ long, with the exception of Transect 1 (Fig. 1) which was $50 \mathrm{~m}$ long. Each transect was surveyed monthly from January 1989 to December 1990, using SCUBA, during daylight hours. In instances of shoals being observed (Gobiusculus flavescens, Pomatoschistus pictus), numbers were estimated to the nearest 5 .

While environmental data and species densities were obtained per $1 \times 2 \mathrm{~m}$, for the purpose of the analyses each transect line was subdivided into discrete microhabitats, which may span more than $1 \times$ $2 \mathrm{~m}$. The microhabitats were defined by the homogeneity of 9 environmental variables, which were: percentage cover of the substratum categories [bedrock, boulders $(>0.50 \mathrm{~m})$, rocks $(0.10$ to $0.49 \mathrm{~m})$, gravel,

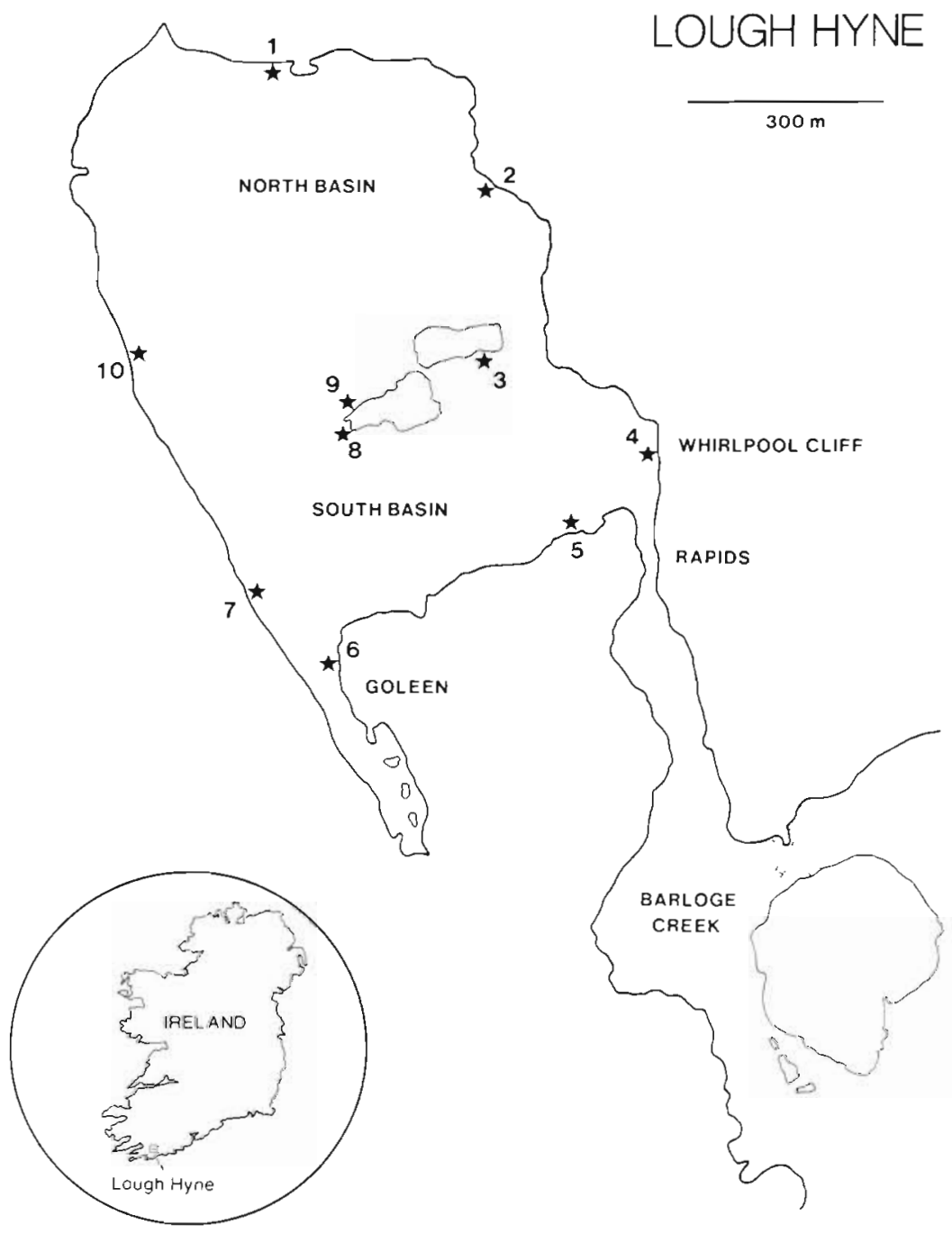

Fig. 1. Lough Hyne, showing position of transect sites muddy shell-gravel, and mud]; depth, measured with a calibrated depth gauge [readings were subsequently converted to depth below the Lough Hyne 'Standard Level' (Bassindale et al. 1948), and average depths were calculated for each microhabitat $]_{i}$ current velocities ( $\mathrm{m} \mathrm{s}^{-1}$ ), taken from Bassindale et al. (1957); algal cover, estimated as mean percentage cover of attached macroalgae during the sampling period. An additional variable recorded was the distance of individuals from substratum, fish being recorded as epibenthic or hyperbenthic (>10 cm above the substratum).

In order to determine seasonal differences, data were pooled into winter 1989 (W1; January to March, mean temperature $\left.(\mathrm{t})=10.1^{\circ} \mathrm{C}, \mathrm{SE} \pm 0.1\right)$, spring 1989 (Sp1; April to June, $\mathrm{t}=11.8^{\circ} \mathrm{C}, \mathrm{SE} \pm 0.4$ ), summer 1989 (Su1; July to September, $\mathrm{t}=15.6^{\circ} \mathrm{C}, \mathrm{SE} \pm 0.3$ ), autumn 1989 (A1; October to December, $t=12.2^{\circ} \mathrm{C}, \mathrm{SE} \pm 0.9$ ), winter 1990 (W2; January to March, $t=9.1{ }^{\circ} \mathrm{C}, \mathrm{SE}$ \pm 0.1 ), spring $1990\left(\mathrm{Sp} 2\right.$; Aprii to June, $t=11.3^{\circ} \mathrm{C}$, $\mathrm{SE} \pm 0.5$ ), summer 1990 (Su2; July to September, $\left.t=14.7^{\circ} \mathrm{C}, \mathrm{SE} \pm 0.2\right)$, and autumn 1990 (A2; October to December, $\mathrm{t}=12.0^{\circ} \mathrm{C}, \mathrm{SE} \pm 0.3$ ).

Data were arranged in 2 matrices: sample by species $(50 \times 64)$, containing densities $\mathrm{m}^{-2}$ on a seasonal basis; and sample by environmental variable $(50 \times 10)$.

In order to test for interspecific differences in microhabitat use, seasonal differences, and environmental variables influencing microhabitat use, matrices were subjected to canonical correspondence analysis (CCA) using the package CANOCO (ter Braak 1987). Species densities were transformed $[\ln (x+1)]$ prior to the analysis. Kruskall-Wallis 1 -way analysis of variance tests were applied to the ordination scores in order to determine any intraspecific seasonal variation.

Preferences for each of the environmental variables were evaluated using Jacobs' (1974) modification of Ivlev's electivity index, as in Copp (1992):

$$
D=\frac{r-p}{r+p-2 r p}
$$

where $r=$ proportion of resource used by a species, and $p=$ proportion of resource available in the environment.

Resource use and availability were determined from measurements of the environmental variables, which were categorised as in Table 1. D is a value 
Table 1. Categories of environmental variables for electivity indices (Figs. 4, 5, 6 \& 7)

\begin{tabular}{|c|c|c|c|c|c|c|c|c|c|}
\hline \multirow[t]{2}{*}{ Variable } & \multicolumn{8}{|c|}{ Category } & \multirow[b]{2}{*}{9} \\
\hline & 1 & 2 & 3 & 4 & 5 & 6 & 7 & 8 & \\
\hline Mud $(\%)$ & Absent & $1-25$ & $26-50$ & $51-100$ & & & & & \\
\hline Rocks $(\%)$ & Absent & $1-25$ & $26-50$ & & & & & & \\
\hline Boulders $(\%)$ & Absent & $1-25$ & $26-50$ & $51-75$ & $76-100$ & & & & \\
\hline Bedrock $(\%)$ & Absent & $1-25$ & $26-50$ & $51-75$ & $76-100$ & & & & \\
\hline Muddy shell-gravel (o) & Absent & $1-25$ & $26-50$ & $51-100$ & & & & & \\
\hline Gravel ("".) & Absent & $1-25$ & $26-100$ & & & & & & \\
\hline Algal cover $(\%)$ & Absent & $1-33$ & $34-66$ & $67-100$ & & & & & \\
\hline Current $\left(\mathrm{m} \mathrm{s}^{-1}\right)$ & Absent & $0.01-0.10$ & $0.11-0.20$ & $0.21-0.35$ & & & & & \\
\hline Depth (m) & $0-2.5$ & $2.6-5.0$ & $5.1-7.5$ & $7.6-10.0$ & $10.1-12.5$ & $12.6-15.0$ & $15.1-17.5$ & $17.6-20.0$ & $20.1-25.0$ \\
\hline $\begin{array}{c}\text { Distance from } \\
\text { substratum }\end{array}$ & Epibenthic & $\begin{array}{l}\text { Hyper- } \\
\text { benthic }\end{array}$ & & & & & & & \\
\hline
\end{tabular}

between -1.0 and 1.0 corresponding with total avoidance and total preference for a given category of environmental variable (Jacobs 1974).

\section{RESULTS}

Fifty microhabitats were defined, with at least 1 species occurring in each microhabitat.

Fig. 2 presents the CCA ordination diagram for the entire assemblage. Only Axes 1 and 2 are presented, as they cumulatively account for $79.7 \%$ of the total variance. The species-environment correlations of each axis were 0.92 (Axis 1), and 0.77 (Axis 2).
Axis 1 is strongly related to distance from substratum, which results in the epibenthic species clustering separately from the hyperbenthic species. Due to the dominating effect of this environmental variable, a second CCA analysis was carried out on the epibenthic species only, with the hyperbenthic species, Gobiusculus flavescens and Pomatoschistus pictus, removed from the analysis. Fig. 3 presents the CCA ordination diagram for the epibenthic species only, Axes 1 and 2 cumulatively accounting for $80.3 \%$ of the total variance. The speciesenvironment correlations of each axis were 0.87 (Axis 1) and 0.86 (Axis 2). Axis 1 was principally correlated with boulders and mud cover, whilst Axis 2 was correlated predominantly with depth and algae.

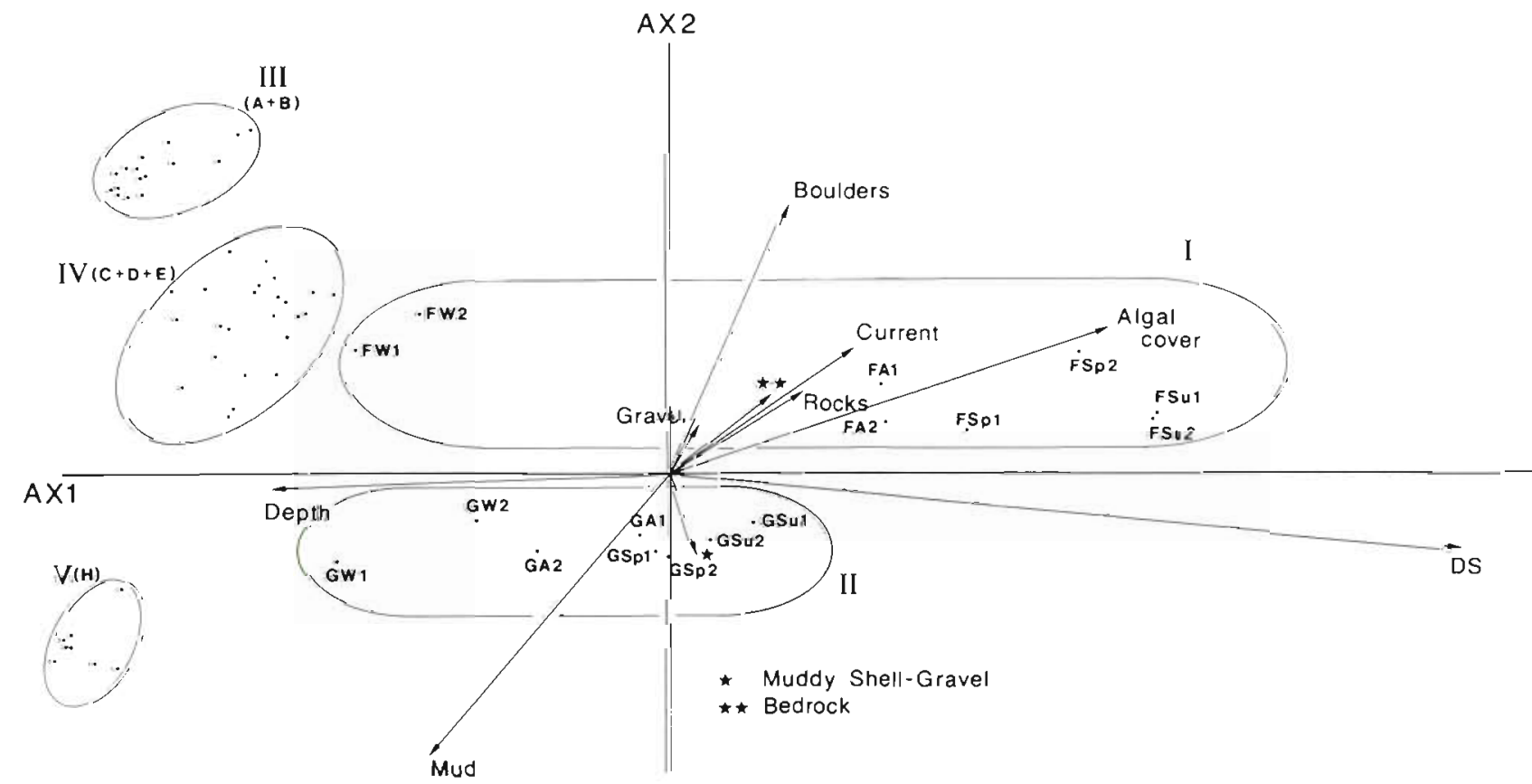

Fig. 2. CCA ordination diagram for all species. $\mathrm{A}=$ Gobius cruentatus, $\mathrm{B}=$ Thorogobius ephippiatus, $\mathrm{C}=\mathrm{G}$. paganellus, $\mathrm{D}=\mathrm{G}$. couchi, $\mathrm{E}=\mathrm{G}$. niger, $\mathrm{F}=$ Gobiusculus flavescens, $\mathrm{G}=$ Pomatoschistus pictus, $\mathrm{H}=P$. minutus, $\mathrm{DS}=$ distance from substratum. W, Sp, Su and A followed by ' 1 ' or '2' represent seasons (see text for details) 


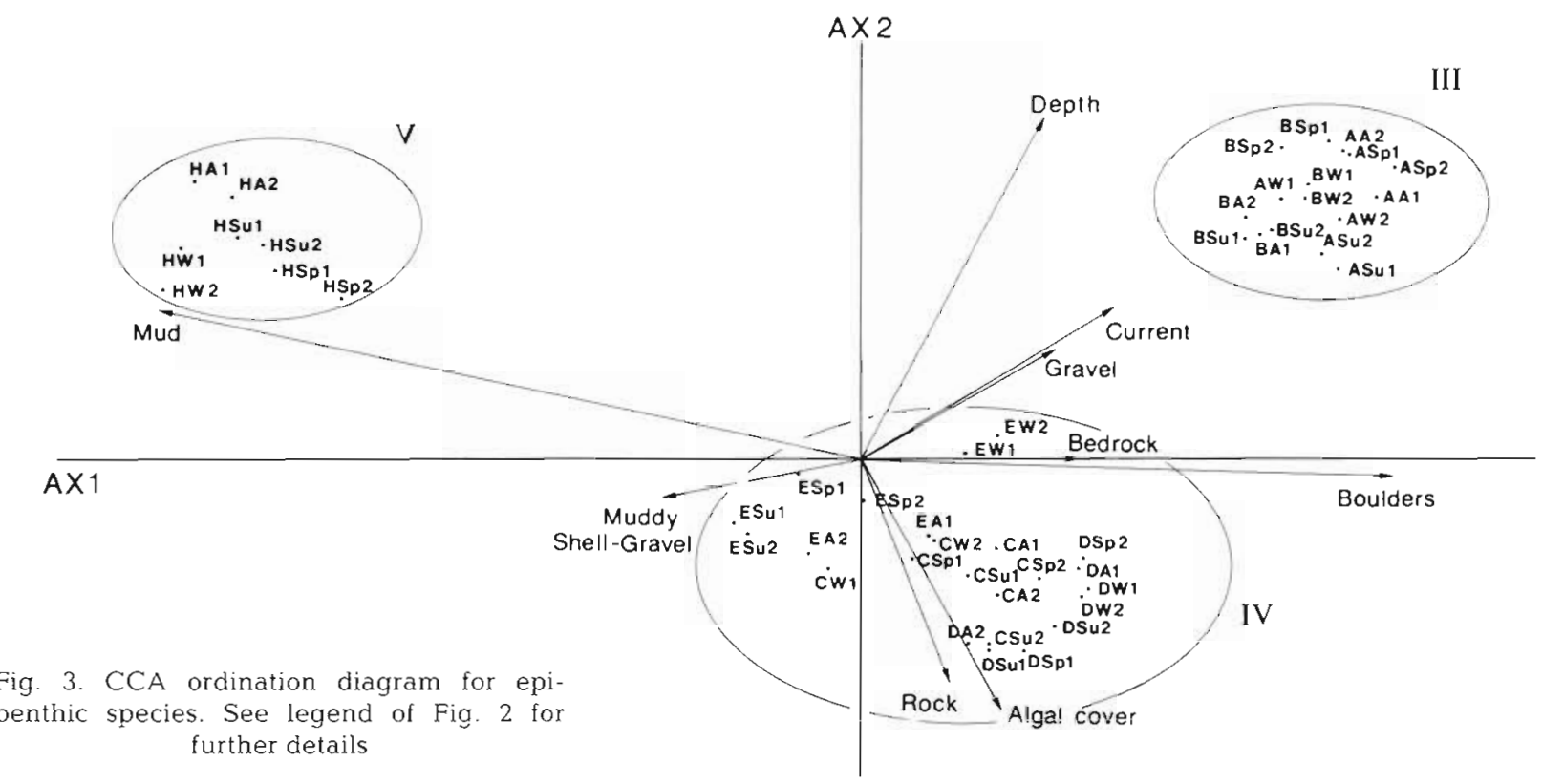

\section{Interspecific differences}

Five clusters of species can be identified (Fig. 2). By projecting the relative position of the species points onto the environmental arrows, it is possible to infer which environmental variables have determined the clustering. The clusters can be grouped into an epibenthic group and a semi-hyperbenthic group; Gobiusculus flavescens and Pomatoschistus pictus make up the semi-hyperbenthic group (clusters I and II), while the remaining species make up the epibenthic group (clusters III, IV, and V) (Fig. 2). It is evident that the presence of algae in a shallow rocky/bouldery area is preferred by G. flavescens, particularly in spring, summer, and autumn when this species is largely hyperbenthic (cluster I), while $P$. pictus prefers areas with mud or muddy shell-gravel in slightly deeper water (cluster II) (Fig. 2). Fig. 3 better clarifies the environmental variables that determine the clustering of the epibenthic species.

Cluster III (Gobius cruentatus and Thorogobius ephippiatus) can be distinguished from the other clusters by its preference for microhabitats containing a high level of boulder cover, in relatively deep water, and with moderate current (Fig. 3).

Cluster IV (Gobius couchi, G. paganellus, G. niger) can be distinguished by its preference for moderate boulder and rock cover, in relatively shallow water, with some degree of algal cover. G. niger can be distinguished from the rest of the cluster by its preference for slightly deeper water with a higher degree of mud cover (Fig. 3).

Cluster V (Pomatoschistus minutus) is distinguished by a preference for areas consisting of nearly uniform mud cover, with no current, or algal cover (Fig. 3).
The proximity of the species ordination points within clusters III and IV (Figs. 2 \& 3 ) suggests microhabitat co-exploitation; however, within these clusters interspecific differences in microhabitat use can be identified from the electivity indices (Fig. 4).

Clusters I and II differ from the other clusters by being hyperbenthic at certain times, whilst the other clusters are epibenthic at all times (Figs. 2 \& 4). The electivity indices for Gobiusculus flavescens (cluster I) show this species to be principally hyperbenthic (Fig. 4). A similar trend is seen in Pomatoschistus pictus (cluster II), however, this species was less specific in its preference (Fig. 4). Differences between these 2 species exist in substratum preferences, with G. flavescens preferring rocky/bouldery areas with high current velocities, whilst $P$. pictus preferred muddy areas with little hard substratum present and no current. G. flavescens also differed from $P$. pictus by preferring shallower water, and a high percentage cover of algae, whilst $P$. pictus extended over a larger depth range, and was relatively indifferent to algal cover (Fig. 4).

While there were many similarities in the microhabitat use of Gobius cruentatus and Thorogobius ephippiatus (cluster III), small differences existed (Fig. 4). The depth preferences of these species were very similar, however $G$. cruentatus extended to slightly shallower depths than T. ephippiatus. G. cruentatus was indifferent to the presence of rocks, and algal cover, whilst $T$. ephippiatus avoided both of these variables. T. ephippiatus preferred areas with low current velocities and relatively high mud cover, whilst $G$. cruentatus preferred areas with moderate to high current velocities, and less mud cover (Fig. 4). 

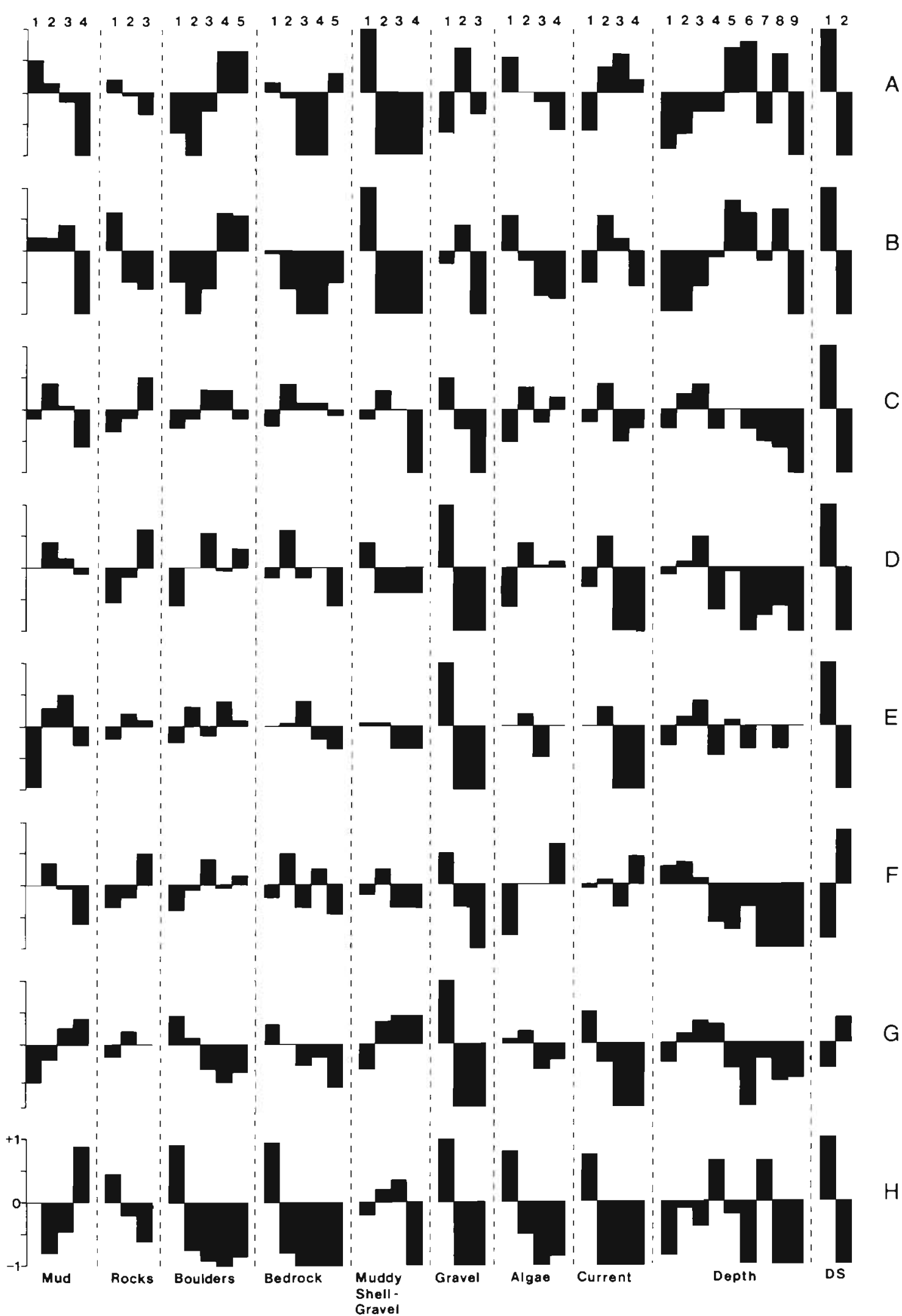

Fig. 4. Electivity indices, pooled over all seasons. See Table 1 for categories of environmental variables, Fig. 2 for abbreviations 
Cluster IV is made up of Gobius paganellus, $G$. couchi, and G. niger. Both G. paganellus and G. couchi preferred depth ranges from -2.5 to $-7.5 \mathrm{~m}$, while $G$. niger extended over a larger depth range. All 3 species preferred low current velocities, although $G$. paganellus was more tolerant of high velocities than $G$. couchi and $G$. niger. All 3 species showed similar patterns in substratum preferences. G. paganellus avoided areas with a high percentage cover of mud, while $G$. couchi was indifferent, and $G$. niger preferred areas with up to $50 \%$ mud cover. G. paganellus was indifferent to the presence of a small amount of gravel, unlike $G$. couchi and $G$. niger, which avoided gravel (Fig. 4).

Pomatoschistus minutus (cluster V) was characterised by its preference for a high percentage cover of mud, with absence of hard substrata, algae and current (Fig. 4).

\section{Seasonal differences}

By performing a Kruskal-Wallis 1-way analysis of variance on the CCA axes scores for each species, it was possible to discern any variation along an axis. Gobiusculus flavescens and Pomatoschistus pictus showed variation along Axis 1 ( $p<0.1$ ) (Fig. 2), as did the epibenthic species, Gobius niger and $P$. minutus (p<0.1) (Fig. 3), whilst $G$. cruentatus and $G$. niger showed variation along Axis $2(p<0.1)$ (Fig. 3). Not all variations along an axis were seasonal in nature, thus Figs. 5 to 7 present only those species and environmental variables that exhibited seasonal patterns in variation.

Gobiusculus flavescens exhibited seasonal variation in distance from substratum, being epibenthic in winter, but predominantly hyperbenthic in summer

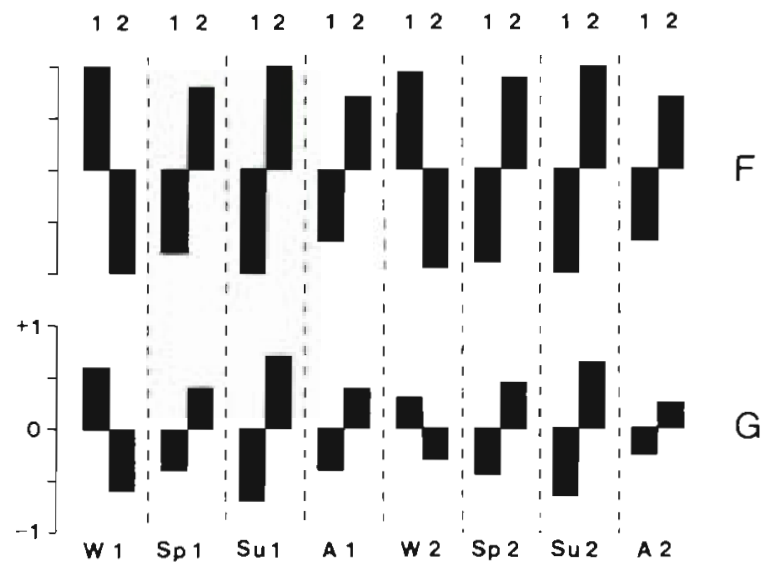

Fig. 5. Electivity indices for seasonal variation in distance from substratum. $\mathrm{F}=$ Gobiusculus flavescens, $\mathrm{G}=$ Pomatoschistus pictus. See Table 1 for categories of this environmental variable

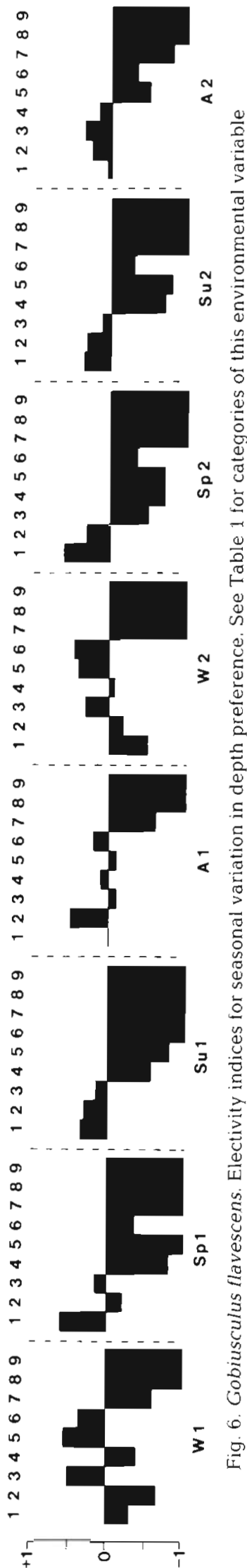




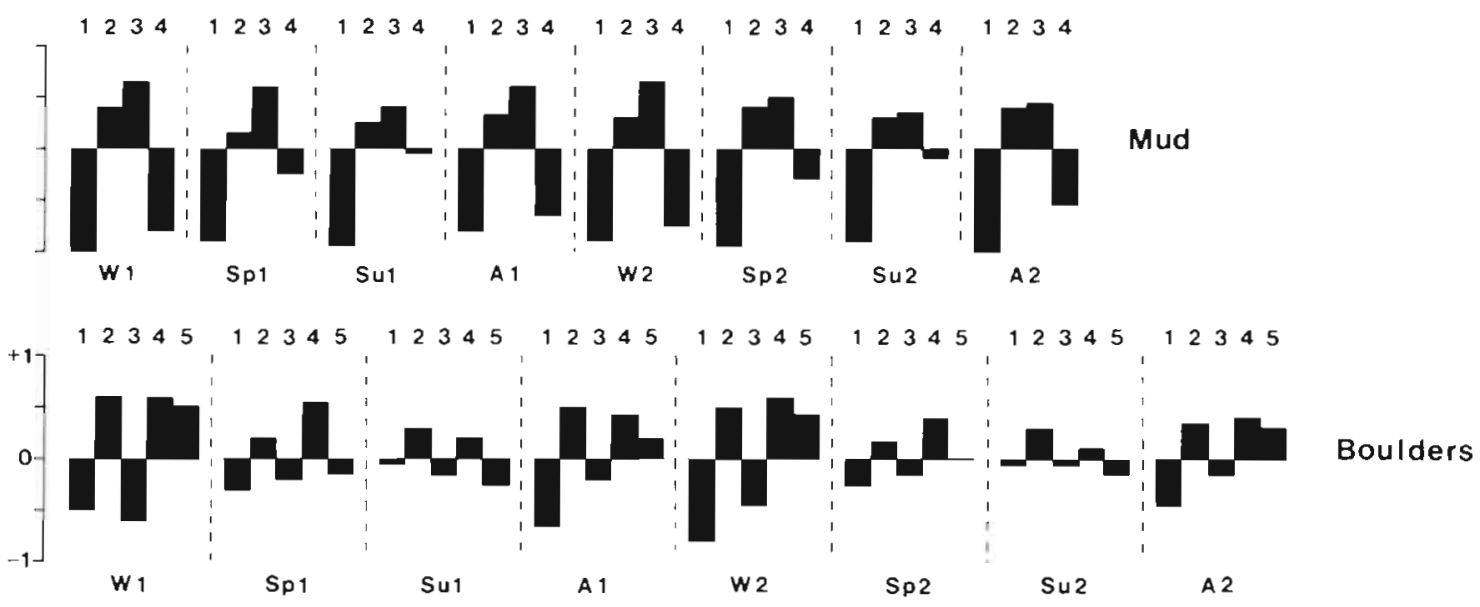

Fig. 7. Gobius niger. Electivity indices for seasonal variation in substratum preference. See Table 1 for categories of these environmental variables

(Fig. 5). G. flavescens preferred very shallow water in summer, but extended into deeper water in winter (Fig. 6).

Pomatoschistus pictus also showed seasonal variation in distance from substratum. This species was found to be both epibenthic and hyperbenthic throughout the year, however in spring and summer this species tended more towards being hyperbenthic (Fig. 5).

Gobius niger showed seasonal variation in its preferences for mud, and boulder cover This species preferred a higher percentage of boulder cover in winter than in summer (Fig. 7). It exhibited an inverse trend in preference for mud cover, avoiding areas of high mud cover in winter, and becoming indifferent to areas of high mud cover in spring and summer (Fig. 7).

\section{DISCUSSION}

The assemblage of Gobiidae at Lough Hyne exhibited non-random microhabitat utilisation. Two major groups can be recognised - epibenthic, and semi-hyperbenthic - and within these, 5 microhabitat guilds (sensu Hawkins \& MacMahon 1989) can be distinguished. The microhabitat guilds can be defined as: (1) a semi-hyperbenthic guild over rocks and boulders in shallow algal-covered areas consisting of Gobiusculus flavescens, (2) an epibenthic guild in the same areas, consisting of Gobius couchi, G. paganellus, and G. niger, (3) an epibenthic guild in relatively deep boulder-covered areas, consisting of $G$. cruentatus and Thorogobius ephippiatus, (4) a semi-hyperbenthic guild over muddy areas with only a small amount of hard substrata present, consisting of Pomatoschistus pictus, and (5) an epibenthic guild on relatively uniform muddy substratum in relatively deep water, which consists of $P$. minutus.
Both Gobiusculus flavescens and Pomatoschistus pictus occupied both the hyperbenthic and the epibenthic realm. These species frequently occur sympatrically (Iglesias 1981, Collins 1982), and similarities in many aspects of their biology exist (Collins 1981, 1982). Previously in Lough Hyne these species have been recorded shoaling together (Costello 1992). Whilst in summer some mixed shoaling did occur (pers. obs,), these species did exhibit a degree of habitat segregation, with $G$. flavescens preferring shallow rocky algal-covered areas, whilst $P$, pictus preferred areas with less hard substrata, and more mud cover, over a greater depth range. G. flavescens was almost always found in association with algae, which Potts \& McGuigan (1986), in a study of juvenile $G$. flavescens, attribute to sheltering from predation; similar reasoning can be applied to adult fish (Wheeler 1980). G. flavescens exhibited seasonal variation in depth preferences, preferring very shallow waters in summer and spring, and extending deeper in winter. Diminishing algal cover in winter may result in $G$. flavescens being more vulnerable to terrestrial predators such as piscivorous birds, particularly in shallow water (Kruuk et al, 1988), thus G. flavescens may move to deeper water as a result of predator pressure. Both $G$. flavescens and $P$. pictus demonstrated seasonal variation in use of the 3 spatial dimensions, with both species occupying the hyperbenthos throughout spring and summer, as well as the epibenthos. Whilst $G$. flavescens became predominantly hyperbenthic in summer, $P$. pictus occurred equally in the epibenthos and the hyperbenthos. In winter, shoaling activity decreased, and both species were mostly found in close association with the substratum, possibly as a result of decreasing activity, associated with decreasing winter temperatures. Small-scale temporal differences in habitat use by $G$. flavescens and $P$. pictus 
were also apparent, with both species becoming closely associated with the substratum at night (Costello 1992, authors' pers. obs.), and during the crepuscular periods (authors' pers. obs.), a phenomenon common in some shoaling reef fish (Hobson 1972).

Occupation of the hyperbenthos over the shallow rocky boulder areas by Gobiusculus flavescens facilitated coexistence, by vertical spatial segregation, with the epibenthic species, Gobius couchi, G. paganellus, and $G$. niger. The latter 3 species all showed overlap in most aspects of their habitat utilisation, however differences did exist. G. couchi and $G$. paganellus are both documented as inhabiting shallow rocky areas (Wilkins \& Myers 1991), whilst $G$. niger has been found in a variety of habitats (Vaas et al. 1975, Nash 1984, Wiederholm 1987, Wilkins \& Myers 1991). In this study G. niger differed from both $G$. couchi and $G$. paganellus in occupying slightly muddier microhabitats over a larger depth range. Dietary analyses of these 3 species inds demonstrated considerable overlap in trophic requirements (MCGrath 1974, Miller \& El-Tawil 1974, Vaas et al. 1975, Dunne 1978, Chesney \& Iglesias 1979), thus competition may occur for food, and microhabitat, particularly between $G$. couchi, and $G$. paganellus.

Gobius niger exhibited seasonal changes in substratum preferences, preferring more open areas in summer than in winter. This may merely be a reflection of decreased activity in winter associated with decreasing temperatures, which results in many benthic species hiding in the substratum (Kotrschal 1983), in this instance boulder crevices. At higher latitudes it has been shown that $G$. niger migrates offshore in winter (Norway; Nash 1984), however, this does not occur at lower latitudes (northwest Spain; Iglesias 1981). The temperature range in Lough Hyne is comparable to that in northwest Spain, which may explain the absence of a winter migration into deeper water by $G$. niger.

Previous studies have remarked on the association of Gobius cruentatus and Thorogobius ephippiatus with hard substrata (Miller 1969, Dunne 1976, Wilkins \& Myers 1991), and the coexistence of these 2 species in Lough Hyne has been noted by Wilkins \& Myers (1991). While overlap in microhabitat utilisation was extensive between $G$. cruentatus and $T$. ephippiatus, differences, reflecting differential requirements or competetive exclusion, were apparent in this study. $T$. ephippiatus preferred areas with more mud cover than $G$. cruentatus, whilst $G$. cruentatus was more tolerant of algae than $T$. ephippiatus. This may reflect the different camouflaging properties of these habitats, $T$ ephippiatus and $G$. cruentatus becoming cryptic in areas with mud and algae respectively.

Pomatoschistus minutus occurred in open muddy areas, showing no microhabitat overlap with other species. $P$. minutus has previously been described as a food generalist obtaining most of its food from the benthos and epibenthos (Hamerlynck et al. 1986), as well as a habitat generalist (Magnhagen \& Wiederholm 1982), occupying open areas and algal-covered areas in equal proportion (Wiederholm 1987). This study showed $P$. minutus to actively avoid the macroalgal cover, however, this species was found in the Audouinella zone (sensu Kitching et al. 1976) in Lough Hyne (pers. obs.), where the algal mat may have afforded cover and/or food. No seasonal depth migrations were observed for $P$. minutus in this study, although many studies have shown $P$. minutus to perform depth migrations to deeper waters in winter months (Fonds 1971, 1973, Healey 1971, Hesthagen $1975,1977,1979$ ).

Jones \& Miller (1966) suggest that such migrations occur only when temperatures fall below $5^{\circ} \mathrm{C}$; as iemperatures in Lough Hyne rareiy fail below $9^{\circ} \mathrm{C}$, this may explain the absence of depth migrations in Lough Hyne. However, Healey (1971) suggests that causation of winter migrations is more complex and cannot be ascribed to temperature alone.

The patterns observed in this assemblage of Gobiidae suggest that habitat segregation is of primary importance, with the 5 microhabitat guilds differentiated on the basis of their distance from substratum, and to a lesser extent by depth, and their differential preferences for mud, boulders, and algal cover. Interactions with non-Gobiidae, differential vulnerability to predation, dietary preferences, morphological and physiological adaptations, and social interactions in addition to historical constraints probably all contribute to segregation of microhabitat guilds (Grossman et al. 1987a, Wiederholm 1987. Copp 1992).

Within microhabitat guilds extensive overlap in microhabitat utilisation existed. Since microhabitat is only a component of the niche, species within microhabitat guilds could segregate along other niche dimensions, however, further studies are required to elucidate whether segregation between microhabitat guild-sharing species is occurring along either trophic or temporal axes.

In summary, 5 guilds were distinguished on the basis of microhabitat utilisation, suggesting the importance of habitat as a niche-segregating mechanism in this assemblage of Gobiidae. Interguild differences were stable both seasonally and annually, suggesting that the existence of the microhabitat guilds may be attributable to evolutionary constraints as well as contemporary competitive interactions. Further investigations are required to determine the relative importance of the various resource dimensions, particularly between microhabitat guild members. 
Acknowledgements. This study was carried out while one of us (H.K.A.W.) was in receipt of a University College Cork scholarship. We gratefully acknowledge the Wildlife Service, Ireland, for permission to carry out this study at Lough Hyne.

\section{LITERATURE CITED}

Baker, J. A., Ross, S. T (1981). Spatial and temporal resource utilisation by southeastern cypriniids. Copeia 1981: $178-189$

Baker, J. M., Crothers, J. H. (1987). Intertidal rock. In: Baker, J. M., Wolff, W. J. (eds.) Biological surveys of estuaries and coasts. Cambridge University Press, Cambridge, p. $157-197$

Bassindale, R., Davenport, E., Ebling, F. J., Kitching, J. A., Sleigh, M. A., Stone, J. F. (1957). The ecology of the Lough Ine rapids with special reference to water currents. VI. The effects of the rapids on the hydrography of the south basin. J. Ecol. 45: 879-900

Bassindale, R., Ebling, F. J., Kitching, J. A., Purchon, R. D. (1948). The ecology of the Lough Ine rapids with special reference to water currents. I. Introduction and hydrography. J. Ecol. 36: 305-322

Behrents Hartney, K. (1989). The foraging ecology of two sympatric gobiid fishes: importance of behaviour in prey type selection. Envir. Biol. Fish. 26: 105-118

Bouchon-Navaro, Y (1986). Partitioning of food and space resources by chaetodontid fishes on coral reefs. J. exp. mar. Biol. Ecol. 103: 21-40

Carr, M. H. (1989). Effects of macroalgal assemblages on the recruitment of temperate zone reef fishes. J. exp. mar. Biol. Ecol. 126: 59-76

Chesney, E. J. Jr, Iglesias, J. (1979). Seasonal distribution, abundance, and diversity of demersal fishes in the Inner Ria de Arosa, NW Spain. Estuar coast. mar Sci. 8 $227-239$

Clarke, R. D. (1977). Habitat distribution and species diversity of chaetodontid and pomacentrid fishes near Bimini, Bahamas. Mar. Biol. 40: 277-289

Collins, S. P. (1981). Littoral and benthic investigations on the west coast of Ireland - XIII. The biology of Gobiusculus flavescens (Fabricius) on the Connemara coast. Proc. R. Ir. Acad. 81B: 63-87

Collins, S. P. (1982). Littoral and benthic investigations on the west coast of Ireland - XIV. The biology of the painted goby, Pomatoschistus pictus (Malm) (Teleostei: Gobiidae) on the Connemara coast. Proc. R. Ir. Acad. 82B: 21-37

Copp, G. H. (1992). Comparative microhabitat use of cyprinid larvae and juveniles in a lotic floodplain channel. Envir. Biol. Fish. 33: 181-193

Costello, M. J. (1992). Abundance and spatial overlap of gobies (Gobiidae) in Lough Hyne, Ireland. Envir. Biol. Fish. 33: 239-248

Costello, M. J., Partridge, J. C., Rogers, S. I., Shand, J. (1990). Habitat and distribution of gobies in Lough Hyne, S.W. Ireland. Prog. Underwat. Sci. 15: 73-84

Dunne, J. (1976). Littoral and benthic investigations on the west coast of Ireland $-V$ (Section A: Faunistic and ecological studies). A contribution to the biology of the leopard spotted goby, Thorogobius ephippiatus (Lowe) (Pisces: Teleostei: Gobiidae). Proc. R. Ir. Acad. 76B: 121-132

Dunne, J. (1978). Littoral and benthic investigations on the west coast of Ireland - IX (Section A: Faunistic and ecological studies). The biology of the rock goby, Gobius paganellus L., at Carna. Proc. R. Ir. Acad. 78B: 179-191

Dyrynda, P. E. J., Farnham, W. F. (1985). Benthic communities of a rapids system within the Fleet Lagoon, Dorset. Prog Underwat. Sci. 10: 65-82

Fonds, M. (1971). The seasonal abundance and vertebral variation of Pomatoschistus minutus minutus and lozanol (Gobiidae) in the Dutch Wadden Sea. Vie Milieu (suppl.) 22: $393-407$

Fonds, M. (1973). Sand gobies in the Dutch Wadden Sea (Pomatoschistus, Gobiidae, Pisces). Neth. J. Sea Res. 6: $417-478$

Gorman, O. T., Karr, J. R. (1978). Habitat structure and stream fish communities. Ecology 59: 507-515

Greenberg, L. A. (1991). Habitat use and feeding behaviour of thirteen species of benthic stream fishes. Environ. Biol. Fish. 31: 389-401

Greenfield, D. W., Johnson, R. K. (1990). Community structure of western Caribbean blennioid fishes. Copeia 1990: $433-448$

Grossman, G. D., de Sostoa, A., Freeman, M. C., CobonCervia, J. (1987a). Microhabitat use in a Mediterranean riverine fish assemblage. Fishes of the lower Matarrana Oecologia 73: $490-500$

Grossman, G. D., de Sostoa, A., Freeman, M. C., CobonCervia, J. (1987b). Microhabitat use in a Mediterranean riverine fish assemblage. Fishes of the upper Matarrana. Oecologia 73: 501-512

Grossman, G. D., Freeman, M. C. (1987). Microhabitat use in a stream fish assemblage. J. Zool., Lond. 212: 151-176

Hamerlynck, O., Heip, C., Redant, F. (1986). Life history, food consumption and resource partitioning in two sympatric gobies, Pomatoschistus minutus, and $P$. lozanoi in the Belgian coastal waters. Comm. Meet. Int. Coun. Explor. Sea C.M.-ICES/L: $14-19$

Hawkins, C. P., MacMahon, J. A. (1989). Guilds: the multiple meanings of a concept. A. Rev. Entomol. 34: 423-451

Healey, M. C. (1971). Distribution and abundance of sand gobies, Gobius minutus in Ythan estuary. J. Zool., Lond 163: $177-229$

Hesthagen, I. H. (1975). Seasonal occurrence and length variation in the sand goby, Pomatoschistus minutus (Pallas), in the shore zone of the inner Oslofjord. Norw. J. Zool. 23: 235-243

Hesthagen, I. H. (1977). Migrations, breeding and growth in Pomatoschistus minutus (Pallas) (Pisces, Gobiidae) in Oslofjorden, Norway. Sarsia 63: 17-26

Hesthagen, I. H. (1979). Temperature selection and avoidance in the sand goby, Pomatoschistus minutus (Pallas), collected at different seasons. Environ. Biol. Fish. 4: 369-377

Hobson, E. S. (1972). Activity of the Hawaiian reef fishes during the evening and morning transitions between daylight and darkness. Fish. Bull. U.S. 70: 715-740

Iglesias, J. (1981). Spatial and temporal changes in the demersal fish community of the Ria de Arosa (NW Spain). Mar. Biol. 65: 199-208

Illich, I. P., Kotrschal, K. (1990). Depth distribution and abundance of northern Adriatic littoral rocky reef blennioid fishes (Blenniidae and Tripterygion). P.S.Z.N. I: Mar. Ecol. 11: $277-289$

Jacobs, J. (1974). Quantitative measurement of food selection, a modification of the forage ratio and Ivlev's electivity index. Oecologia 14: 413-417

Jones, D., Miller, P. J. (1966). Seasonal migrations of the Common Goby, Pomatoschistus microps (Kroyer), in Morecambe Bay and elsewhere. Hydrobiologia 27: 515-528

Kitching, J. A., Ebling, F. J., Gamble, J. C., Hoare, R., McLeod, A. Q. R., Norton, T. A. (1976). The ecology of Lough Ine. XIX. Seasonal changes in the Western Trough. J. anim. Ecol. 45: 731-758 
Kotrschal, K. (1983). Northern adriatic rocky reef fishes at low winter temperatures. P.S.Z.N. I: Mar. Ecol, 4: 275-286

Kruuk, H., Nolet, B., French, D. (1988). Fluctuations in numbers and activity of inshore demersal fishes in Shetland. J. mar. biol. Ass. U.K. 68:601-617

Lindquist, D. G. (1985). Depth zonation, microhabitat, and morphology of three species of Acanthemblemaria (Pisces: Blennioidea) in the Gulf of California, Mexico. P.S.Z.N. I: Mar. Ecol 6: 329-344

Luckhurst, B. E., Luckhurst, K. (1978). Analysis of the influence of substrate variables on coral reef fish communities. Mar. Biol. 49: 317-323

Magnhagen, C., Wiederholm, A. (1982). Habitat and food preference of Pomatoschistus minutus and $P$. microps (Gobidae) when alone and together, an experimental study. Oikos 39: 152-156

McGrath, D. (1974). Preliminary studies on the feeding of Gobius niger (L.) and Gobiusculus flavescens (Fabricius) (Pisces, Gobiidae) in the northern Baltic proper. Contr. Askö Lab., Univ. Stockholm, 4

Miller, P. J. (1969). Systematics and biology of the leopard spotted goby, Gobius ephippiatus (Teleostei: Gobiidae), with description of a new yenus and notes on the identity of G. macrolepis Kolombatović. J. mar. biol. Ass. U.K. 49: $831-855$

Miller, P. J. (1986). Gobiidae. In: Whitehead, P. J. P., Bauchot, M.-L., Hureau, J.-C., Nielsen, J., Tortonese, E. (eds.) Fishes of the north-eastern Atlantic and the Mediterranean, Vol. III. UNESCO, Paris, p. 1019-1085

Miller, P. J., El-Tawil, M. Y (1974). A multidisciplinary approach to a new species of Gobius (Teleostei: Gobiidae) from southern Cornwall. J. Zool., Lond. 174: 539-574

Minchin, D. (1988). Couch's goby, Gobius couchi (Teleostei Gobiidae) from Irish waters. J. Fish Biol. 33: 821-822

Myers, A. A., Little, C., Costello, M. J., Partridge, J. C. (eds.) (1991). The ecology of Lough Hyne. Royal Irish Academy, Dublin

Nash, R. D. M. (1984). Aspects of the biology of the black goby, Gobius niger L., in Oslofjorden, Norway. Sarsia 69: $55-61$

Paine, M. D., Dodson, J. J., Power, G. (1982). Habitat and food resource partitioning among four species of darters

This article was submitted to the editor
(Percidae: Etheostoma) in a southern Ontario stream. Can. J. Zool. 60: 1635-1641

Pitts, P. A. (1991). Comparative use of food and space by three Bahamian butterflyfishes. Bull. mar. Sci. 48: 749-756

Potts, G. W., McGuigan, K. M. (1986). Preliminary survey of the distribution of post larval fish associated with inshore reefs, and with special reference to Gobiusculus flavescens (Fabricius). Prog. Underwat. Sci. 11: 15-25

Robertson, D. R., Lassig, B. (1980). Spatial distribution patterns and coexistence of a group of territorial damselfishes from the Great Barrier Reef. Bull. mar. Sci. 30: 187-203

Ross, S. T. (1986). Resource partitioning in fish assemblages: a review of field studies. Copeia 1986: $352-388$

Schoener, T. W. (1974). Resource partitioning in ecological communities. Science 185: 27-39

Smith, C. L., Tyler, J. C. (1973). Direct observations of resource sharing in coral reef fish. Helgoländer wiss Meeresunters. 24: $264-275$

ter Braak, C. J. F. (1987). CANOCO - a FORTRAN program for canonical community ordination by [partial] [detrended] [canonical] correspondence analysis, principle components analysis and redundancy analysis (version 2. 1). Agricuilturai Mathematics Group, Wageningen

Vaas, K. F., Vlasblom, A. G., De Koeijer, P. (1975). Studies on the black goby (Gobius niger, Gobiidae, Pisces) in the Veerse Meer, SW Netherlands. Neth. J. Sea Res. 9: $56-68$

Werner, E. E., Hall, D. J., Laughlin, D. R., Wagner, D. J., Wilsmann, L. A., Funk, F. C. (1977). Habitat partitioning in a freshwater fish community. J. Fish. Res. Bd Can. 34: $360-370$

Wheeler, A. (1980). Fish-algal relations in temperate waters In: Price, J. A., Irvine, D. E. G., Farnham, W. F. (eds.) The shore environment, Vol. 2: Ecosystems. Academic Press, London, p. 677-698

Wiederholm, A. M. (1987). Habitat selection and interactions between three marine fish species (Gobiidae). Oikos 48: $28-32$

Wilkins, H. K. A., Myers, A. A. (1991). The distribution of gobies (Teleostei: Gobiidae). In: Myers, A. A., Little, C., Costello, M. J., Partridge, J. C. (eds.) The ecology of Lough Hyne. Royal Irish Academy, Dublin, p. 107-115

Manuscript first received: June 16, 1992

Revised version accepted: December 1, 1992 